\title{
REGIONAL DIFFERENTIATION \\ OF THE SERVICE SECTOR DEVELOPMENT \\ IN SELECTED EUROPEAN COUNTRIES
}

\author{
IGOR KAVETSKYY \\ University of Szczecin, Faculty of Geosciences, POLAND \\ e-mail: igor.kavetskyy@usz.edu.pl
}

RECEIVED
ACCEPTED
JEL
CLASSIFICATION

KEYWORDS European countries, regional differentiation, service sector, tertiarisation

ABSTRACT The aim of the work is to assess the contemporary state of structural changes in the service sector in the basic territorial division units of France, Germany, Poland and Ukraine, with particular emphasis on the group of producer and business services considered as one of the leading factors of regional development differentiation. Very significant differences were found in the level of development and structure of regional service systems of the countries surveyed, which essentially reflect their different socio-economic experience. Attention was also paid to the presence of certain universal, typical for all considered countries, developmental regularities, which concern primarily the concentration of producer and business services in the most prosperous regions. They constitute, in each case, specific poles of growth, in which the most important developmental impulses are transferred successively to other territorial units of the country.

\section{Introduction}

Currently, in the majority of developed countries, the participation of the services sector in generating GDP and total employment exceeds $60-70 \%$ and shows a tendency to further increase. This process is determined in the source literature as tertiarisation understood primarily as a global process of infiltration of services to all other types of activity and transformation of this sector into the leading domain of socio-economic development 
(Peneder, Kaniowski, Dachs, 2003). Numerous empirical studies carried out on materials from various countries (e.g. Beyers, 2005; Bryson, Rusten, 2005; Deza, López, 2014; Genaro, Melchor, 2010; Jennequin, 2008; Moyart, 2003; Skórska, 2016) underline the widespread nature of this phenomenon and its resonant influence on the development of the studied countries, as well as the special role of services for entrepreneurs in this process, referred to as producer, business, professional, advanced, knowledge-intensive etc. They are considered as a kind of driving force of national and regional production systems due to the high potential of implementing modern forms of management and organization of work, transfer of new technologies or adaptation of local enterprises to the changing conditions of production and trading (Moyart, 2003).

A natural element of the development of the services sector is its regional differentiation resulting from various kinds of geographical-historical and socio-demographic factors, the specificity of the institutional environment and external relations, dominant social beliefs and political and legal norms etc. At the same time, it should be taken into account that the very dynamic development of producer and business services observed in recent years may contribute to the increase of regional inequalities due to the specific predispositions of this type of services to focus on urban areas, especially in large cities and agglomerations (Deza, López, 2014).

Therefore, the aim of this work is to assess the current state of structural changes of the service sector in the regions of selected European countries, with particular emphasis on the group of producer and business services considered as one of the leading factors of regional development differentiation. The study covered the basic units of the territorial division of four countries: France, Germany, Poland and Ukraine. These countries, in addition to a relatively large area and population, are characterized by a well-diversified structure of the economy. At the same time, they form a continuous latitudinal orientation line, which can be interpreted as the main European geoeconomic vector, where France represents a developed market economy, Germany is an example of integration of the market economy (western part) with the transformed economy (eastern part, former GDR), Poland is a young market economy, while Ukraine is still somewhat a transforming country.

In the case of three EU countries, the material for research comes from the electronic database Eurostat (2018), while the data for Ukraine was taken from the website of the State Statistics Service of Ukraine (2018). Comparable and at the same time complete data was collected at the beginning of 2016. Regional level adopted - territorial units of the second level of NUTS in the configuration from 2013: 22 regions of France (excluding 5 overseas units), 38 administrative districts of Germany and 16 Polish voivodships. In the case of Ukraine, 25 oblasts and a city of special status - Kyiv were considered as equivalents. The analysis omits the areas currently outside the reach of the Ukrainian authorities, i.e. the Autonomous Republic of Crimea, the city of special status Sevastopol and the uncontrolled parts of the Donetska and Luhanska oblasts. The data was aggregated at the first NACE level, i.e. the section according to the PKD nomenclature. The work grouped individual sections into 5 contractual groups defined as: agriculture, forestry and fishing (section A), industry and construction (sections B-F), traditional market services (G-I sections), producer and business services (sections $\mathrm{J}-\mathrm{N}$ ) and public and personal services (O-U sections). In this way, service activities are co-created by the last three classes whose content generally reflects the heterogeneous structure of the modern service sector. The assessment of the development of individual activity groups is made using three basic measures: percentage share in total employment in the region, percentage share in regional GVA and GVA per 1,000 employed persons. 


\section{The location of the services sector in the overall structure of the economies under study}

According to data from the World Bank (2018) in the period from the beginning of the 90s of the 20th century, France shows the most advanced tertiarisation among the countries surveyed, where services accounted for $65.5 \%$ of total employment and $62.8 \%$ of GDP in 1991 . Until 2017 these values increased by 17.1 and $13.3 \%$, respectively. In Germany, the share of services in employment in 1991 was $55 \%$, but by 2017 it increased by $29.9 \%$, almost as much as the value observed in France. As for the structure of GDP, the role of services increased in the discussed period from 56.3 to $61.9 \%$. The situation in the other two countries looks different. It was not until 1996 when Poland achieved a 50\% share of the services sector in GDP, and in 1999 - in employment. Ukraine, in turn, defeated this conventional border in 2001 with regard to the employment structure and in 2008 as regards the GDP indicator. Both countries, however, are characterized by significantly higher dynamics, especially in terms of employment in Poland (mediumterm growth rate at $1.5 \%$ ) and production in Ukraine (2.2\% annually). As a consequence, in 2017 the share of the services sector in total employment in both countries approached 60\%. As regards GDP, in Poland at the end of the discussed period, the relevant ratio reached $58.3 \%$, while in Ukraine it was $50.3 \%$. However, it is worth noting that in 2013 it was 56.3\%, and its reduction in the following years is related to Ukraine's loss of Crimea and Donbas areas.

A detailed picture of the structure of the analysed economies, including the division into five groups of activities mentioned in the introduction, is illustrated in Figure 1. It is not difficult to notice that the observed structural differences essentially reflect the location of the surveyed countries on the main European geo-economic vector, and the size of these discrepancies very well represent labour productivity indicators measured by the GVA amount in relation to the number of persons employed (Table 1).
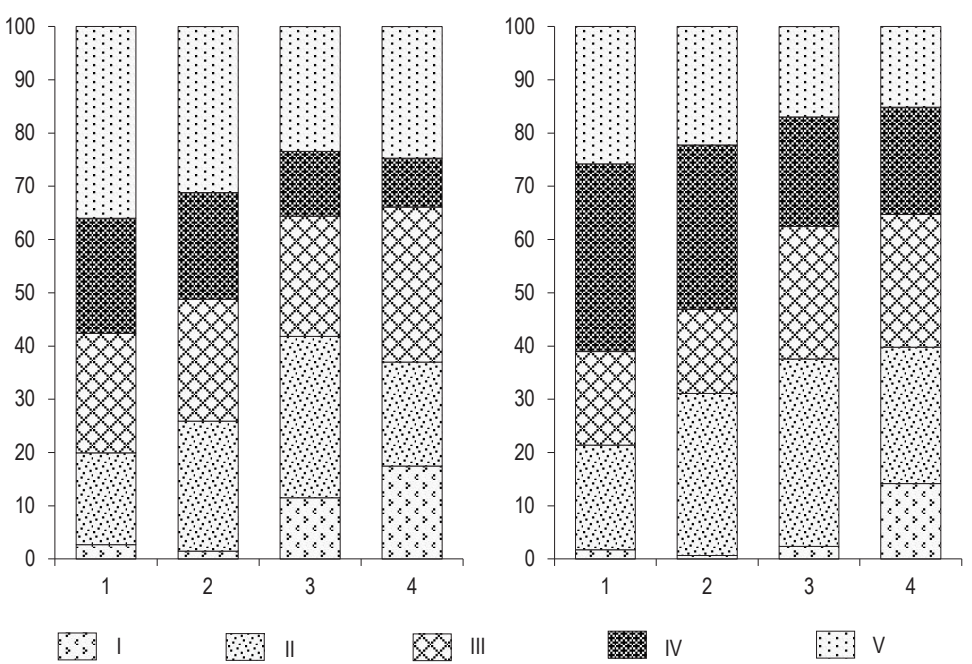

1 - France, 2 - Germany, 3 - Poland, 4 - Ukraine; I - Agriculture, forestry and fishing, II - Industry and construction, III - Traditional market services, IV - Producer and business services, V - Public and personal services.

Figure 1. Structure of the economy of the surveyed countries by employment (on the left) and GVA (on the right), at the beginning of $2016(\%)$

Source: own study based on Eurostat (2018); State Statistics Service of Ukraine (2018). 
Table 1. Labour productivity in particular activity groups of the countries surveyed at the beginning of 2016 (EUR million/1,000 employees)

\begin{tabular}{|c|c|c|c|c|c|}
\hline Country & $\begin{array}{c}\text { Agriculture, forestry } \\
\text { and fishing }\end{array}$ & $\begin{array}{l}\text { Industry and } \\
\text { construction }\end{array}$ & $\begin{array}{c}\text { Traditional market } \\
\text { services }\end{array}$ & $\begin{array}{c}\text { Producer and business } \\
\text { services }\end{array}$ & $\begin{array}{c}\text { Public and personal } \\
\text { services }\end{array}$ \\
\hline France & 46.5 & 81.5 & 56.1 & 116.5 & 51.3 \\
\hline Germany & 27.2 & 79.1 & 43.6 & 97.8 & 45.2 \\
\hline Poland & 5.0 & 27.8 & 26.4 & 40.2 & 17.3 \\
\hline Ukraine* & 3.4 & 5.5 & 3.6 & 9.3 & 2.6 \\
\hline
\end{tabular}

"Calculated in accordance with the annual average exchange rate of the hryvnia to the euro, which in 2015 was UAH 2422,87 for 100 euros.

Source: own study based on Eurostat (2018); State Statistics Service of Ukraine (2018).

Apart from the detailed analysis of each of the separated classes, one should pay attention to the unique position of the group of producer and business services. Despite the lowest employment rates (compared to two other service sectors), this type of services plays the most important role in creating the structure of GVA in France and Germany, contributing about 1/3 to the total GVA. As regards Poland and Ukraine, this group of services provides about $20 \%$ of the total value of final goods and services, giving way to leading positions in the industrial sector and traditional market services. At the same time, in each of the surveyed countries, the highest labor productivity rates are associated with producer and business services, although their values in the case of Poland and especially Ukraine indicate a huge distance to Western countries.

\section{Regional differentiation of the development of the services sector}

While the data at the level of entire countries allow to build their fairly clear hierarchies with regard to the level of tertiarisation of the economy, the image at the regional level is more complex. In the aggregate list, the highest development rates of service activities are mainly related to the French and, to a lesser extent, German regions. In turn, the lowest indicators are mainly characteristic for the Ukrainian regions and, in part, also for the Polish regions. The indicated regularity is also reflected in the mean values calculated separately for each of the analysed countries (Table 2). However, in this case, it seems more important to draw attention to interregional differences within individual countries that are visible in the coefficient of variation. Each time, the position of Ukraine stands out in a special way, where the coefficient is an order of magnitude higher than in other countries. In the case of the efficiency index, it assumes a value of $59.9 \%$, which corresponds to almost six times higher value of a given index in Kyiv in relation to its size in the Chernivetska oblast.

It is easy to notice the leading positions of the capital regions of particular countries, in which the maximum values of the analysed indicators are recorded consistently (with the exception of the Germany). The importance of these regions is highlighted in particular by their share in the domestic GVA volumes generated in services. In the case of Kyiv, it is a value of $34 \%$, while in the second largest Dnipropetrovska oblast it is only $7.5 \%$. The situation is similar in France, where the capital region of Île-de-France provides $33.6 \%$ of the total value of services, ahead of the second one, the region of Rhône-Alpes by 24,4 percentage points, and in Poland, where the share of Mazowieckie voivodeship is $25.5 \%$ is 2.3 times higher than the index of the second Silesian voivodship. The situation is different in Germany, where Berlin with the value of $5 \%$ occupies only the 6th position in the country, giving way to Stuttgart, Köln, Darmstadt, Düsseldorf and Oberbayern. The share of each of these regions ranges from 5.2 to $8 \%$. 
Table 2. Basic descriptive statistics of the development of the services sector in the surveyed countries at the beginning of 2016 in the regional cross-section

\begin{tabular}{|c|c|c|c|c|c|c|}
\hline Country & Mean & SD & CV & $\operatorname{Max}$ & Min & Max/Min \\
\hline \multicolumn{7}{|c|}{ Share in employment, \% } \\
\hline France & 77.1 & 3.8 & 5.0 & Île de France (88.1) & Franche-Comté (72.3) & 1.2 \\
\hline Germany & 72.9 & 6.0 & 8.2 & Berlin (88.1) & Niederbayern (63.2) & 1.4 \\
\hline Poland & 57.0 & 4.4 & 7.7 & Mazowieckie (66.1) & Świętokrzyskie (49.3) & 1.3 \\
\hline Ukraine & 60.9 & 7.5 & 12.4 & Kyiv (87.8) & Luhanska (53.0) & 1.7 \\
\hline \multicolumn{7}{|c|}{ Share in GVA, \% } \\
\hline France & 74.6 & 5.0 & 6.7 & Île de France (86.8) & Franche-Comté (67.9) & 1.3 \\
\hline Germany & 67.6 & 6.9 & 10.3 & Berlin (84.5) & Stuttgart (55.5) & 1.5 \\
\hline Poland & 60.9 & 4.4 & 7.3 & Mazowieckie (71.6) & Lubuskie (55.2) & 1.3 \\
\hline Ukraine & 53.4 & 11.2 & 20.9 & Kyiv (88.2) & Poltavska (32.7) & 2.7 \\
\hline \multicolumn{7}{|c|}{ GVA per number of employees, million EUR/1,000 people } \\
\hline France & 63.1 & 7.3 & 11.5 & Île de France (94.3) & Champagne-Ardenne (58.8) & 1.6 \\
\hline Germany & 56.2 & 7.0 & 12.4 & Hamburg (76.6) & Chemnitz (46.5) & 1.6 \\
\hline Poland & 23.5 & 4.8 & 20.5 & Mazowieckie (33.5) & Lubelskie (17.2) & 2.0 \\
\hline Ukraine $^{*}$ & 3.2 & 1.9 & 59.9 & Kyiv (12.0) & Chernivetska (2.0) & 6.0 \\
\hline
\end{tabular}

$\star$ Calculated in accordance with the annual average exchange rate of the hryvnia to the euro.

Source: own study based on Eurostat (2018); State Statistics Service of Ukraine (2018).

Considering the structure of the services sector divided into three groups (traditional market services, producer and business services as well as public and personal services), it is necessary to state slightly different patterns of the general layout of these groups in individual countries (Table 3). In the case of France and Germany, in almost

Table 3. Selected descriptive statistics of the development of particular groups of service activities in the surveyed countries at the beginning of 2016 in the regional cross-section

\begin{tabular}{|c|c|c|c|c|c|c|c|c|c|}
\hline \multirow{2}{*}{ Country } & \multicolumn{3}{|c|}{ Traditional market services } & \multicolumn{3}{|c|}{ Producer and business services } & \multicolumn{3}{|c|}{ Public and personal services } \\
\hline & mean & SD & $\mathrm{CV}$ & mean & $\mathrm{SD}$ & $\mathrm{CV}$ & mean & SD & $\mathrm{CV}$ \\
\hline \multicolumn{10}{|c|}{ Share in employment, $\%$} \\
\hline France & 28.3 & 1.5 & 5.2 & 23.1 & 4.1 & 18.0 & 48.6 & 4.0 & 8.3 \\
\hline Germany & 31.5 & 2.3 & 7.3 & 25.2 & 4.7 & 18.6 & 43.3 & 3.7 & 8.5 \\
\hline Poland & 39.6 & 2.2 & 5.7 & 18.4 & 4.7 & 25.5 & 42.0 & 3.7 & 8.8 \\
\hline Ukraine & 46.6 & 3.4 & 7.4 & 11.8 & 5.3 & 45.1 & 41.6 & 5.0 & 12.0 \\
\hline \multicolumn{10}{|c|}{ Share in GVA, \% } \\
\hline France & 22.8 & 2.0 & 8.8 & 38.3 & 5.4 & 14.2 & 38.9 & 5.1 & 13.0 \\
\hline Germany & 23.3 & 2.7 & 11.6 & 41.8 & 5.4 & 13.0 & 34.9 & 5.4 & 15.4 \\
\hline Poland & 40.8 & 2.5 & 6.1 & 28.4 & 5.7 & 20.0 & 30.8 & 4.5 & 14.6 \\
\hline Ukraine & 38.3 & 6.9 & 17.9 & 27.6 & 4.8 & 17.5 & 34.1 & 7.9 & 23.1 \\
\hline \multicolumn{10}{|c|}{ GVA per number of employees, million EUR/1,000 people } \\
\hline France & 50.8 & 6.5 & 12.8 & 105.2 & 10.3 & 9.8 & 50.1 & 3.0 & 6.0 \\
\hline Germany & 41.8 & 7.5 & 18.0 & 94.3 & 13.5 & 14.4 & 44.6 & 2.2 & 5.0 \\
\hline Poland & 24.3 & 5.4 & 22.2 & 36.7 & 6.8 & 18.5 & 16.9 & 2.4 & 13.9 \\
\hline Ukraine & 2.8 & 2.4 & 86.2 & 7.4 & 2.1 & 27.9 & 2.4 & 0.7 & 27.8 \\
\hline
\end{tabular}

Source: own study based on Eurostat (2018); State Statistics Service of Ukraine (2018). 
all regions, the largest share in terms of employment is occupied by public and personal services, while the lowest values are related to producer and business services. As far as GVA is concerned, in both countries' regions are found a leading position of public and personal services (in both cases these are mainly north-eastern regions), as well as producer and business (west and south of both countries), while the lowest values consistently are associated with traditional market services. The situation is different in Poland, where the regions with the leading position of public and personal services (eastern and western voivodships) predominate in terms of employment, but the whole central line - from the Pomorskie voivodeship to Śląskie and Małopolskie voivodships - is characterized by the advantage of traditional market services. The last ones become a dominant group when the GVA indicator is taken as the basis. When it comes to Ukraine, the role of traditional market services is the most important in terms of employment and GVA in the vast majority of regions. In both countries, Poland and especially Ukraine, almost all regions have the weakest positions of producer and business services. However, they are characterized by the highest values in all regions of the countries surveyed in terms of labour productivity indicators.

\section{Producer and business services on a regional basis}

As already mentioned, services related to the servicing of production processes and provided mainly to entrepreneurs are increasingly becoming a key factor for socio-economic development and regional competitiveness. This means that despite very large differences between the countries surveyed in the values of the analysed indicators, it is necessary to assume the existence of certain universal (typical for all considered countries) spatial regularities in the development of a given group of services. In order to capture them, the relevant indicators have been converted into indexes by referring values from each region to the average in a given country. The obtained values were used to group regions, assigning them first to two different classes designated as type $A$ (when at least 2 of the 3 indexes were above the average for a given country) and type B (if at least 2 of the 3 indexes were below the average in country). Subsequently, in each case, sub-types 1 and 2 were separated, taking as a criterion the size of one standard deviation (Figure 2).

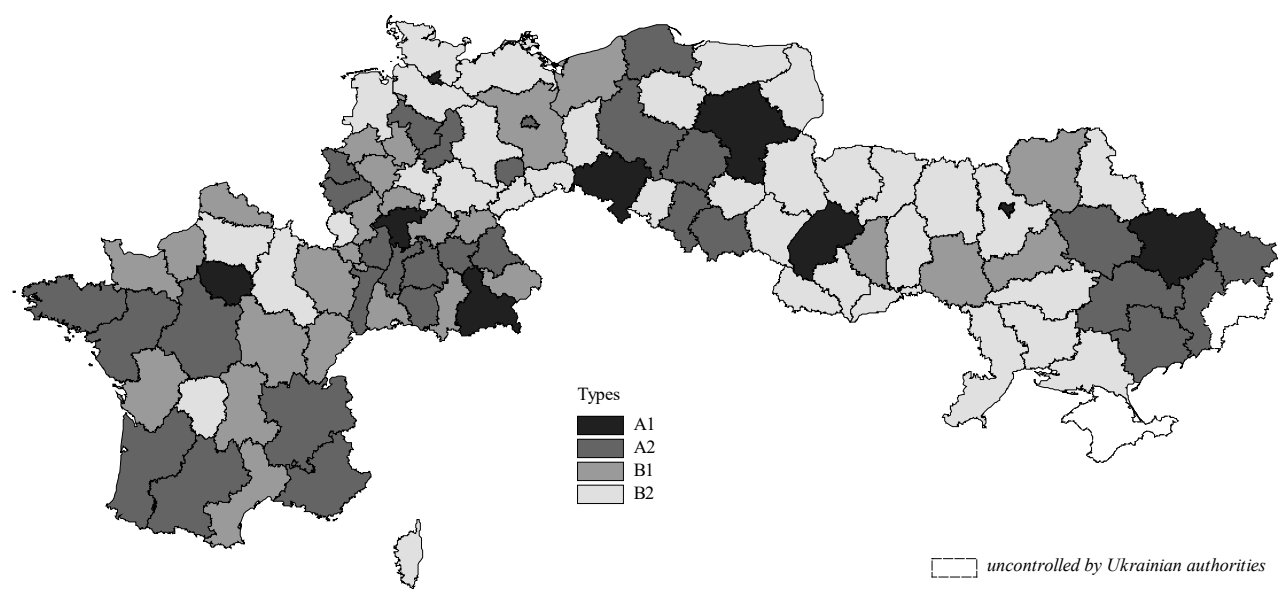

Figure 2. Grouping of regions of the studied countries according to the level of development of producer and business services Source: own study based on Eurostat (2018); State Statistics Service of Ukraine (2018). 
Regions belonging to type $\mathrm{A} 1$ are units with a high level of development of producer and business services in each of the countries discussed. They should be considered as specific growth poles, characterized by a strong competitive position and the most dynamic development pace. It is these regions that stand out in terms of the level of modernization of the economy, the innovation potential and the multiple and intense interregional and international links, while at the same time creating appropriate developmental patterns, transferred successively to other units of the country. In three cases, these are the capital regions (Île de France in France, the Mazowieckie voivodeship in Poland and Kyiv in Ukraine), which strongly dominate the space of their countries, providing $34.5-44.9 \%$ of the value of relevant services. The Dolnośląskie voivodship in Poland and the Lvivska and Kharkivska oblasts in Ukraine should be regarded as small (auxiliary) poles, which have a chance to develop fully only with time. What concerns Germany, then here should be talked about the multipolar model, because all three centres (Oberbayern, Darmstadt and Hamburg) are characterized by comparable indicators of development of the discussed group of services.

A2 and B1 type regions characterized by the development of producer and business services at a level close to the average in a given country are quite numerous represented, not rarely creating larger continuous areas. Usually, these are regions that are fairly well developed in terms of industry (especially those classified as A2). It can therefore be assumed that the presence of a potential consumer turned out to be one of the most important factors stimulating the development of relevant services here. This does not mean, of course, that the creation of many enterprises could not be related to the availability of good infrastructure for running a business. Finally, the last, type B2, associated with the lowest level of development of producer and business services and occurring particularly in Ukraine, is represented mainly by the poorest in socio-economic, mostly agrarian regions. Although in other countries there are less areas of this type, they are quite typical and most often referred to as problematic: eastern regions of Poland (the so-called Poland B), the greater part of the territory of the former GDR in Germany or the least populated Corsica and Limousin in France.

\section{Conclusions}

The conducted research has shown that the process of tertiarisation now affects all analysed countries and has a significant impact on economic processes taking place in their regional units. However, the level of advancement of this process is very diverse and manifests itself in two basic dimensions. The first of these is the country's location on the main European geo-economic vector. Accordingly, the French and German regions are characterized by significantly higher development rates and a more modern structure of the services sector in comparison with the Polish and especially Ukrainian regions.

The second dimension is related to the character and experience of individual regions within each country separately. Urbanized regions with a more diversified structure of the economy, in particular well-developed industrial processing, turn out to be much better prepared to adopt modern service activities. Thanks to the development of producer and business services, they distance themselves from other regions, especially those of an agricultural nature. In this way regional disparities increase, which is particularly evident in the example of Ukraine, where, unlike EU countries, there are no such extensive programs aimed at increasing regional economic and social cohesion.

One should also emphasize the perspective role of prosperous regions in terms of the development of services, especially producer and business. By taking the role of growth poles, they will promote the spread of positive development impulses to neighbouring regions, thus contributing to the overall civilization progress of the country. 


\section{References}

Beyers, W.B. (2005). Services and the changing economic base of regions in the United States. Service Industries Journal, 25 (4), 461-476.

Bryson, J.R., Rusten, G. (2005). Spatial divisions of expertise: Knowledge intensive business service firms and regional development in Norway. Service Industries Journal, 25 (8), 959-977.

Deza, X.V., López, M.G. (2014). Regional Concentration of Knowledge-Intensive Business Services in Europe. Environment and Planning C: Politics and Space, 32 (6), 1036-1058.

Eurostat (2018). Regional statistics by NUTS classification. Retrieved from: https://ec.europa.eu/eurostat/web/regions/data/database.

Genaro, D., Melchor, E. (2010). The impact of the tertiarization process in Spanish economic growth from a regional perspective. Service Industries Journal, 30 (3), 359-374.

Jennequin, H. (2008). The evolution of the geographical concentration of tertiary sector activities in Europe. Service Industries Journal, 28 (3), 291-306.

Moyart, L. (2003). The Role of Producer Services in Regional Development: What Opportunities for Medium-Sized Cities in Belgium? The Service Industries Journal, 25 (2), 213-228.

Peneder, M., Kaniowski, S., Dachs, B. (2003). What Follows Tertiarisation? Structural Change and the Role of Knowledge-Based Services. The Service Industries Journal, 23 (2), 47-66.

Skórska, A. (2016). Determinanty i perspektywy rozwoju sektora usług w Polsce - zmiany wewnątrzsektorowe. Prace Komisji Geografii Przemysłu Polskiego Towarzystwa Geograficznego, 30 (4), 7-20.

State Statistics Service of Ukraine (2018). Multidomain statistical information. Retrieved from: www.ukrstat.gov.ua.

World Bank (2018). World Development Indicators. Retrieved from: https://databank.worldbank.org/data/source/world-developmentindicators.

Cite this article aS: Kavetskyy, I. (2018). Regional differentiation of the service sector development in selected European countries. European Journal of Service Management, 4 (28/2), 193-200. DOI: 10.18276/ejsm.2018.28/2-24. 